\title{
THE SALP RITTERIELLA OFF THE ENGLISH COAST-A CORRECTION
}

\author{
By J. H. Fraser, D.Sc. \\ Marine Laboratory, Aberdeen
}

In a recent short note in this fournal (Fraser, 1954), the occurrence was announced, off the entrance to the English Channel, of the solitary form of the salp Ritteriella picteti (Apstein), and seven aggregate forms of $R$. amboinensis (Apstein), taken by H.M.S. Challenger in 1953. The identification of the aggregate forms as R. amboinensis and not as R.pictet $i$ was based, as then stated, on Thompson's (I948) description from a very young specimen of $R$. picteti which emphasized the similarity of its muscle arrangements to those of Salpa cylindrica and not to Ritteriella amboinensis.

Since this was written, Berner (I954) has described the aggregate form of $R$. pictet $i$ from good specimens found off the west coast of U.S.A., and he has shown that the musculature was in fact not like that of Salpa cylindrica but very similar to Ritteriella amboinensis. Differences were noted in the number of fibres constituting the various body muscles and in the number and arrangement of the oral muscles. A still more recent paper by Yount (1954) includes comparisons of the two forms, based on Berner's characters but also including differences in the length of the endostyle and in body shape (length of anterior and posterior processes, and degree of extension of the gut outside the rest of the body). Yount also goes into greater detail in describing the oral musculature in the two species.

A re-examination of the specimens taken by H.M.S. Challenger shows them to be in fairly close agreement with both Berner's and Yount's descriptions of $R$. picteti, but with one or two small differences. The actual number of fibres in the muscles is rather smaller than given by Berner for $R$. picteti, though the precise figure is difficult to ascertain, and there is no median interruption of the first sphincter muscle in the upper lip which Berner believed to be characteristic, and which Yount accepted. I am particularly grateful to $\mathrm{Mr}$ Berner for sending me some of his material for comparison and, although I certainly found this interruption in his specimens I do not regard its absence from the Atlantic specimens, or their slightly fewer fibres, as significant differences. Such variations in the musculature are not unexpected, and Sewell (1926), for example, gives a warning (p. 67) against regarding interruptions of muscles, their branching or joining, as diagnostic characters.

Again, the differences in the length of the endostyle and body processes appear to be variable with size, and there is in the Atlantic specimens a range 
from short blunt processes with the endostyle extending only to M. 5 in the smallest specimen to long filiform processes and extended endostyle in the largest specimens. It thus seems unlikely that these characters can be used diagnostically as Yount suggests.

However, the Atlantic specimens have the four ventral oral muscles as described in detail by Yount and the number of muscle fibres, though less than given by Berner, is considerably greater than that for $R$. amboinensis. In a personal communication Dr H. Thompson tells me that he accepts Berner's description of the aggregate form of $R$. picteti which was based on much more extensive material, and he agrees that his statement (I948) that it has muscle arrangements resembling that of Salpa cylindrica can now be ignored. I therefore conclude that the seven aggregate specimens taken by H.M.S. Challenger are indeed Ritteriella picteti and I wish to correct the original statement. This satisfactorily disposes of the apparent but somewhat surprising coincidence of two most unusual species of salp.

\section{REFERENCES}

BERNER, L., I954. On the previously undescribed aggregate form of the pelagic tunicata Riteriella picteti (Apstein) (1904). Pacif. Sci., Vol. 8, pp. I2I-4.

FrASER, J. H., I954. Warm-water species in the plankton off the English Channel entrance. F. Mar. biol. Ass. U.K., Vol. 33, pp. 345-6.

SEwELL, R. B. S., I926. Salps of the Indian seas. Rec. Indian Mus., Vol. 28, pp. 65-I26.

Thompson, H., 1948. Pelagic Tunicates of Australia, I96 pp. Melbourne: Council for Sci. Industr. Res., Australia.

Yount, J. L., I954. The taxonomy of the Salpidae (Tunicata) of the Central Pacific Ocean. Pacif. Sci., Vol. 8, pp. 276-330. 